\title{
Peripheral Cell Types Contributing to the Hyperalgesic Action of Nerve Growth Factor in Inflammation
}

\author{
Clifford J. Woolf, Qing-Ping Ma, Andrew Allchorne, and Stephen Poole \\ Department of Anatomy and Developmental Biology, University College London, London WC1E 6BT, United Kingdom
}

\begin{abstract}
The contribution of nerve growth factor (NGF) to inflammatory hyperalgesia potentially could be mediated by any of the three peripheral cell types that express trkA, the high-affinity NGF receptor: inflammatory cells, sympathetic neurons, and primary sensory neurons. To investigate their relative involvement, the effects of sympathectomy and mast cell degranulation were examined on the local inflammation produced by an intraplantar injection of complete Freund's adjuvant in the adult rat. Sympathectomy, produced by neonatal guanethidine treatment, elevated basal NGF levels in the skin but did not attenuate a further increase in NGF during inflammation. Although the onset of inflammatory hyperalgesia was delayed in sympathectomized animals, peak sensitivity was not affected and was
\end{abstract}

still NGF-dependent. In contrast, mast cell degranulation produced by several days of treatment with the cationic secretagogue compound 48/80, while also increasing basal NGF levels, prevented a further increase in NGF levels and attenuated hypersensitivity during inflammation. Neither manipulation modified the inflammatory upregulation of interleukin-1 $\beta$. We conclude that sympathetic neurons contribute transiently to inflammatory hyperalgesia, but that mast cells and sensory neurons are important sites for the sustained action of NGF in producing increased sensitivity during inflammation.

Key words: pain; inflammation; neurotrophins; cytokines; sensory neurons; mast cells; sympathetic nervous system
A cardinal feature of inflammation is pain and hypersensitivity. This originates both in the periphery and in the CNS. In the periphery, inflammatory mediators increase the sensitivity of highthreshold nociceptors so that a lower stimulus intensity is required to activate them, the phenomenon of peripheral sensitization (Treede et al., 1992). In the CNS, sensory signals activated by tissue damage initiate a prolonged use-dependent synaptic facilitation in the spinal cord, the phenomenon of central sensitization, whereby sensory inputs are amplified and normally innocuous inputs may begin to elicit pain (Woolf, 1983). A major contributor to the production of inflammatory hyperalgesia has been shown recently to be the neurotrophin nerve growth factor (NGF). The level of NGF rises substantially in inflamed tissue (Weskamp and Otten, 1987; Donnerer et al., 1992; Woolf et al., 1994) secondary to an earlier rise in the cytokine interleukin-1 $\beta$ (IL-1 $\beta$ ) (SafiehGarabedian et al., 1995), and the administration of anti-NGF serum (Lewin et al., 1994; Woolf et al., 1994) or trkA-IgG fusion proteins (McMahon et al., 1995) substantially reduces inflammatory hypersensitivity. What is not known is the mechanism or site of NGF action during inflammation.

The contribution of NGF to inflammatory sensitivity changes may be local to the site of the inflammation-directly or indirectly sensitizing nociceptors (Lewin et al., 1994). A peripheral action of NGF could be mediated by NGF stimulating inflammatory cells to release neuroactive cytokines or inflammatory mediators (Otten

\footnotetext{
Received Nov. 1, 1995; revised Jan. 16, 1996; accepted Jan. 22, 1996.

This work was supported by Sandoz and the Medical Research Comncil of Great Britain, and the Hannah Research Institute, Ayrshire. We thank B. SafiehGarabedian for assisting with the anti-NGF production.

Correspondence should be addressed to Professor Clifford J. Woolf, Department of Anatomy and Developmental Biology, University College London, Gower Street, London WC1E 6BT, UK.

Dr. Poole's present address: National Institute for Biological Standards and Control, Potters Bar, Hertfordshire, EN6 3QG, UK.

Copyright $\odot 1996$ Society for Neuroscience $0270-6474 / 96 / 162716-08 \$ 05.00 / 0$
}

et al., 1987; Bischoff and Dahinden, 1992). Mast cells, for example, degranulate on exposure to NGF (Mazurek et al., 1986; Pearce and Thompson, 1986; Horigome et al., 1993), and the consequent release of amines, cytokines, or enzymes (Harvima et al., 1994; Marshall and Bienenstock, 1994) may cause acute sensitivity increases by acting on nociceptor terminals (Lewin et al., 1994). Alternatively, the NGF may bind directly to $t r k A$ receptors on the peripheral terminals of primary sensory neurons (McMahon et al., 1994; Smeyne et al., 1994; Averill et al., 1995) and, in a tyrosine kinase-mediated manner (Kaplan et al., 1991b), phosphorylate key transduction-related proteins or ion channels, sensitizing the peripheral terminal. Finally, NGF might produce its local sensitizing actions via the sympathetic nervous system. Postganglionic sympathetic neurons express trkA (Smeyne et al., 1994) and interact with primary sensory neurons to produce the neurogenic component of inflammation (Levine et al., 1985; Coderre et al., 1991; Green et al., 1993). An involvement of the sympathetic nervous system in the behavioral sensitivity induced by inflammation is, however, controversial and has been both proposed (Levine et al., 1986; Nakamura and Ferreira, 1987) and refuted in different studies (Lam and Ferrell, 1991; Perrot et al., 1994). Sympathectomy does, however, substantially reduce the transient hyperalgesia produced by intraplantar NGF administration in the rat (Andreev et al., 1995), which has been interpreted as indicating that activation of these neurons is necessary for the hyperalgesic effects of NGF to manifest.

The action of NGF may not be restricted, however, to the site of its production. On binding to trk $A$, the NGF-trk $A$ complex is internalized and retrogradely transported to the dorsal root ganglion (DRG) (DiStetano et al., 1992), where transcriptional changes (Lindsay and Harmar, 1989) may alter the central effects of nociceplor activation. An upregulation of neuropeptides or other neuromodulators (Leslie et al., 1995) could contribute, for example, by 
amplifying or prolonging synaptic responses in the spinal cord, to the central generation of pain and hypersensitivity.

To investigate which peripheral cells NGF interacts with during inflammation to produce hyperalgesia, we have compared the effect of chemical sympathectomy (Aberdeen et al., 1990; Woolf ct al., 1992) and depletion of mast cells with the cationic sectragogue compound 48/80 (Coderre et al., 1989; Lewin et al., 1994; Mousli et al., 1994) on the capacity of the inflammation produced by an intraplantar injection of complete Freund's adjuvant (CFA) to upregulate IL-1 $\beta$ and NGF and to modify behavioral hypersensitivity.

\section{MATERIALS AND METHODS}

All experiments were performed on adult male (180-300 gm) SpragueDawley rats.

Induction of inflammation. CFA ( $100 \mu \mathrm{l}$; Sigma, St. Louis, MO) was injected into the plantar surface of the left hindpaw under halothane anesthesia (4\%) (Stein et al., 1988). The animals with inflamed paws did not display any loss of weight, changed sleep-wake cycles, disruption of grooming, or social behavior.

Behavioral measurements. Mechanical hyperalgesia was assessed as the reduction in the mechanical threshold of the flexion withdrawal reflex using monofilament nylon von Frey hairs $(0.82-72 \mathrm{gm})$ as described in detail previously (Safieh-Garabedian et al., 1995). Thermal hyperalgesia was assessed as the reduction in the latency to foot withdrawal in a standard hot plate $\left(50^{\circ} \mathrm{C}\right)$ test (Safieh-Garabedian et al., 1995). Data are expressed either as actual threshold or withdrawal times or as a positive normalized value of sensitivity calculated according to the formula: $[(x+$ $y) / x)] \%$, where $x=$ preinflamed values and $y=$ value at a particular time postinflammation.

ELISA assays. The entire hindpaw skin on each side of CFA-treated and age- and weight-matched naive noninflamed animals was dissected free, weighed, and flash-frozen on dry ice. The skin was homogenized in PBS containing $0.4 \mathrm{M} \mathrm{NaCl}, 0.05 \%$ Tween $20,0.5 \%$ bovine serum albumin, $0.1 \mathrm{mu}$ phenylmethylsulfonyl fluoride, $0.1 \mathrm{~mm}$ benzethonium chloride, $10 \mathrm{mM}$ EDTA, and $20 \mu \mathrm{l} \cdot \mathrm{ml}^{-1}$ aprotinin (Sigma). The supernatant was used for measurements both of NGF and IL-1 $\beta$ levels.

NGF was measured using a two-site ELISA, based on the mcthod of Weskamp and Otten (1987), with modifications as detailed previously (Safieh-Garabedian et al., 1995). A polyclonal rabbit anti-NGF antibody raised in our laboratory against HPLC-purified murine NGF and shown by chick DRG neurite assay and ELISAs not to recognize brain-derived neurotrophic factor or neurotrophin-3 was used as the coating antibody. Murine NGF (Promega, Madison, WI) was used as standard, and a rat anti-NGF (diluted 1:20,000) monoclonal antibody (23c4) (Weskamp and Otten, 1987) was used as the detecting antibody.

IL-1 $\beta$ was measured using a two-site ELISA based on a protocol described previously (Taktak et al., 1991; Safieh-Garabedian et al., 1995). Immunoaffinity-purified sheep polyclonal anti-rat IL- $\beta$ antibodies $\left(2 \mu \mathrm{g} \cdot \mathrm{ml}^{-1}\right)$, raised against recombinant rat IL-1 $\beta$, were used to coat microtiter plates, recombinant rat IL-1 $\beta$ (a generous gift from Dr. Robert Newton, DuPont NEN, Wilmington, DE) was uscd as standard and biotinylated, and immunoaffinity-purified sheep polyclonal anti-rat IL-1 $\beta$ $(1: 1000)$ antibodies were used as detecting antibodies.

For both assays, the color was developed by using streptavidin-peroxidase (Dako, High Wycombe, UK) and the chromogen 3,3',5, $5^{\prime}$, tetramethyl-benzidine (Sigma), and the optical density was measured at $450 \mathrm{~nm}$. Results from inflamed skin are expressed as $\mathrm{ng} /$ hindpaw, because the weight of the inflamed paw skin can increase more than twofold.

Sympathectomy. To irreversibly sympathectomize rats, neonatal pups were treated with guanethidine at $50 \mathrm{mg} \cdot \mathrm{kg}^{-1}$ daily for 2 weeks (postnatal days 8-21) (Aberdeen et al., 1990). Depletion of norepinephrine (determined by HPLC) and absence of tyrosine hydroxylase immunohistochemistry of the skin confirmed the effectiveness of this protocol.

Mast cell degranulation. An ascending series of doses of compound $48 / 80$ (Sigma), starting with $25 \mu \mathrm{g}$ (i.p.) on the first day, $60 \mu \mathrm{g}$ on the second day, $125 \mu \mathrm{g}$ on the third day, and two injections of $200 \mu \mathrm{g}$ on the fourth day, was used. This protocol has been shown to degranulate peripheral mast cells reliably (Coderre et al., 1989).

Statistical analysis. Data are presented as mean \pm SEM. Differences between experimental groups and controls were analyzed by one-way ANOVA followed by Dunnett's multiple comparison test or by Welch's or Student's $t$ test, as appropriate.

\section{Thermal Sensitivity}

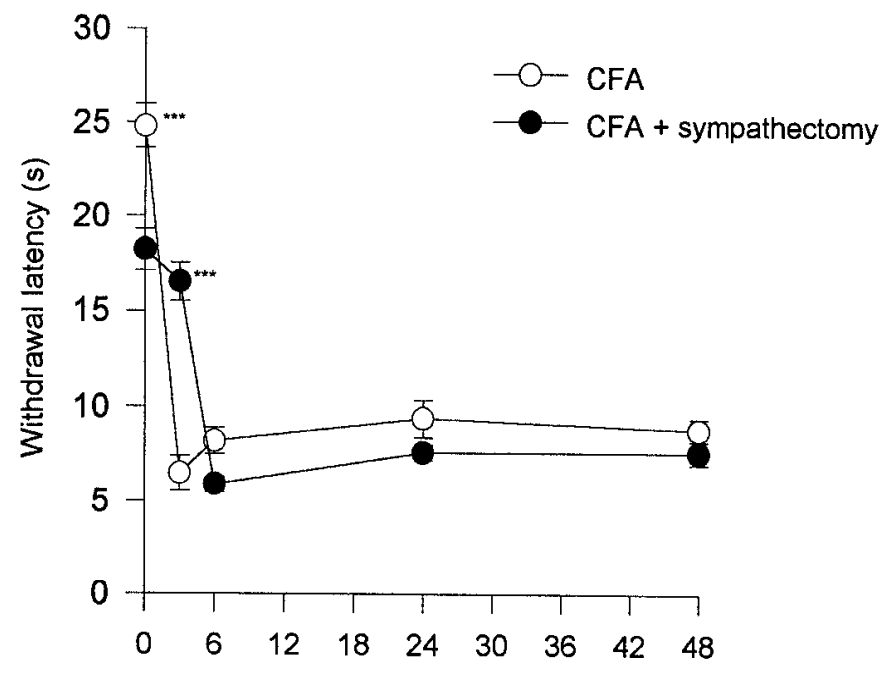

Mechanical Sensitivity

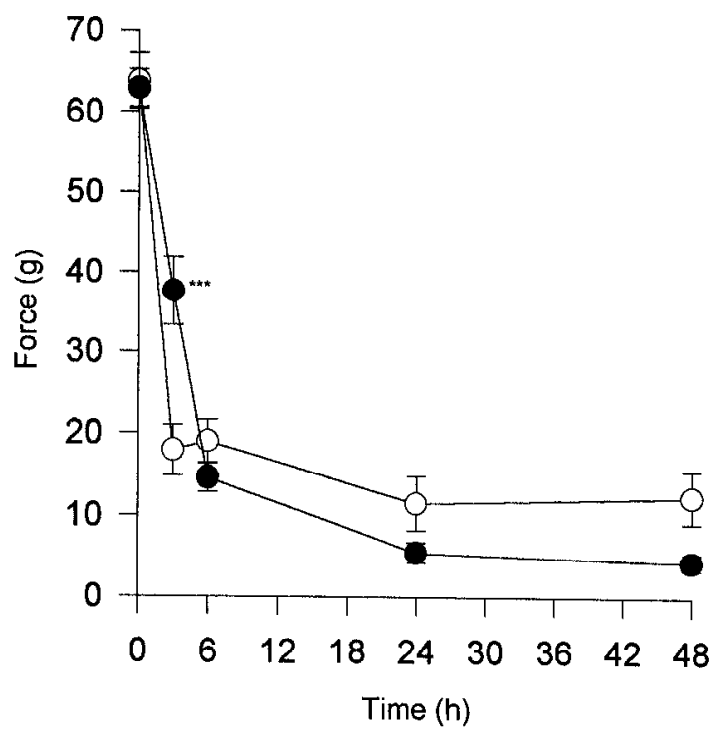

Figure 1. Effect of sympathectomy on the thermal and mechanical hyperalgesia, assessed by $50^{\circ} \mathrm{C}$ hotplate response latency and the flexion reflex mechanical threshold, produced by intraplantar CFA. $n=5$ for CFA group; $n=9$ for sympathectomized animals $\left[{ }^{* * *} p<0.001\right.$ CFA (open circles) vs CFA + sympathectomy (filled circles) groups].

\section{RESULTS}

\section{Inflammation, IL-1 $\beta, N G F$, and hyperalgesia}

Intraplantar injection of $100 \mu$ l of CFA into the left hindpaw of adult male Sprague-Dawley rats resulted in erythema, swelling, and sensory hypersensitivity. Three hours after CFA injection, both thermal and mechanical sensitivity, as assessed by changes in hot plate withdrawal latency and flexor reflex mechanical thresholds, were markedly increased with mean sensitivity values of 176 and $172 \%$, respectively. This persisted for the $48 \mathrm{hr}$ duration of the experiments (Fig. 1). The inflammation also significantly increased IL- $1 \beta$ and NGF levels in the hindpaw, as reported previously (Safich-Garabedian et al., 1995), compared both with noninflamed skin from the same animals and with a control group 


\section{IL-1 $\beta$}

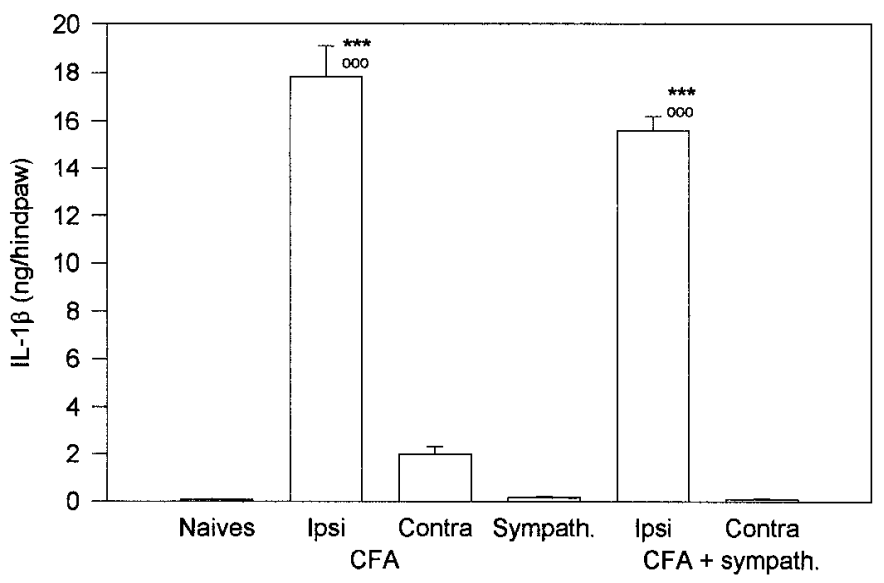

NGF

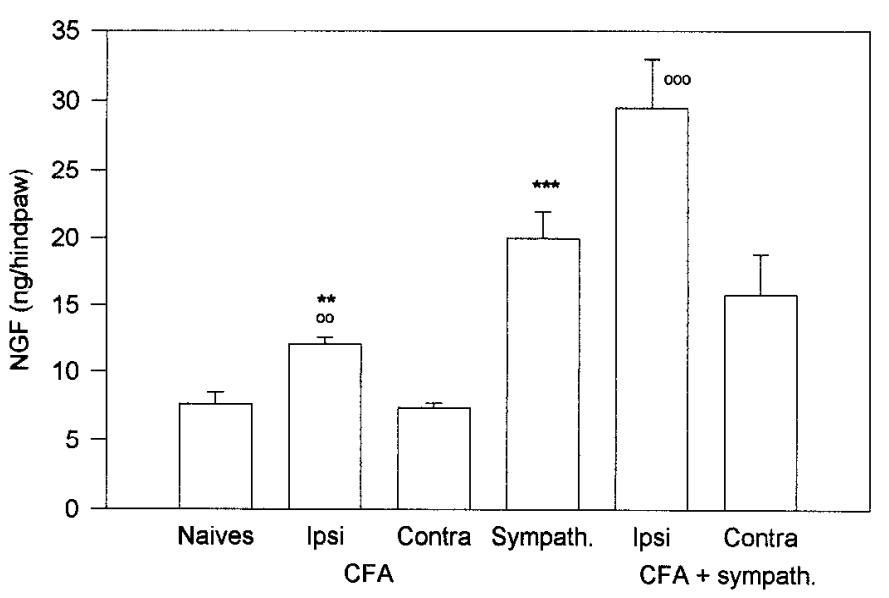

N 11

5

6

8

Figure 2. Sympathectomy did not alter the inflammatory upregulation of IL- $1 \beta$ or NGF measured $48 \mathrm{hr}$ after CFA injections, but did result in an elevated basal level of NGF [oo, ooo, ipsilateral vs contralateral $p<0.01$, $<0.001 ;{ }^{* *},{ }^{* * *}$, ipsilateral $(C F A)$ versus naive or ipsilateral $(C F A+$ sympath. $)$ versus sympathectomized noninflamed (Sympath. $) p<$ $0.01,<0.001]$.

(Fig. 2). An elevation in NGF levels from baseline values in noninflamed rats $(7.65+0.82 \mathrm{ng} / \mathrm{hindpaw} ; n=11)$ was found at $2 \mathrm{hr}$ after CFA injection to $9.25 \pm 0.6 \mathrm{ng} / \mathrm{hindpaw}(n=5)$, with a further increase at $6 \mathrm{hr}$ to $13.9 \pm 1.1 \mathrm{ng} / \mathrm{hindpaw}(p<0.001, n=$ $5)$; stabilization was found at elevated levels at $24 \mathrm{hr}(11.1 \pm 1.4$ $\mathrm{ng} / \mathrm{hindpaw} ; p<0.05, n=5)$ and $48 \mathrm{hr}(12.2 \pm 0.7 \mathrm{ng} / \mathrm{hindpaw}$ $p<0.01, n=5$ ).

\section{Sympathectomy and inflammation}

The thermal but not the mechanical sensitivity of noninflamed sympathectomized animals was increased over littermates, and the onset and extent of the inflammatory hyperalgesia produced by intraplantar CFA was significantly delayed from 3 to $6 \mathrm{hr}$ (Fig. 1). At $3 \mathrm{hr}$, the sympathectomized rats generated a mean thermal sensitivity increase of only $9 \%$ and a mechanical increase of $38 \%$, well below that found in nonsympathectomized animals at this time point. The peak sensitivity measured $6-48 \mathrm{hr}$ after CFA
Table 1. Reduction in thermal and mechanical sensitivity $24 \mathrm{hr}$ after the induction of adjuvant inflammation produced by anti-NGF serum $(\alpha$ NGF)

\begin{tabular}{lccccc} 
& \multicolumn{2}{l}{ Control } & & \multicolumn{2}{c}{ Sympathectomized } \\
\cline { 2 - 3 } \cline { 5 - 6 } & CFA & CFA $+\alpha$ NGF & CFA & CFA $+\alpha$ NGF \\
\hline Thermal & $159.8 \pm 2$ & $120.1 \pm 3.9^{* * *}$ & $156.8 \pm 3.7$ & $121.8 \pm 14^{* * *}$ \\
Mechanical & $182.1 \pm 1.7$ & $143.9 \pm 5.9^{* *}$ & $189.3 \pm 2.8$ & $157.5 \pm 0.3^{* *}$ \\
$n$ & 16 & 16 & 9 & 4
\end{tabular}

${ }^{* *} p<0.01, * * * p<0.001$, Mann-Whitney $U$ test. Sensitivity is expressed as the relative change in the thermal responsiveness and mechanical threshold produced by the CFA injections, where a reduction in withdrawal latency or in mechanical threshold is converted to a positive normalized value according to the formula: $[(x+y) / x] \%$, where $x=$ preinflamed values and $y=$ value at 24 hr postinflammation. The data have been normalized because of the difference in the baseline values after sympathectomy (Fig. 1). 'I'he $\alpha \mathrm{NGH}$ was injected $1 \mathrm{hr}$ before the CFA and has been shown to neutralize NGF but not brain-derived neurotrophic factor or neurotrophin-3 in chick DRG neurite outgrowth assays (Woolf et al., 1994).

injection did not differ, however, from that measured in animals with intact sympathetic nervous systems (Fig. 1).

The basal level of NGF in the skin of sympathectomized rats was more than double that found in control animals (Fig. 2). CFA inflammation continued, however, to elevate NGF levels in the sympathectomized animals with a similar relative increase to that found in animals with intact sympathetic nervous systems (Fig. 2). The capacity of the inflammation to upregulate $\mathrm{IL}-1 \beta$ levels was quite unaffected by sympathectomy (Fig. 2). As in control animals, noninflamed sympathectomized animals had very low basal lcvels of IL-1 $\beta$ (Fig. 2).

To assess whether the inflammatory hyperalgesia present at 24 hr after CFA in sympathectomized animals had an NGFdependent component, a specific neutralizing anti-NGF antiserum (Woolf et al., 1994) was administered 1 hr before the CFA injection in sympathectomized and control rats (Table 1). In animals with an intact sympalletic nervous system, CFA produced a $60 \%$ increase in thermal and an $80 \%$ increase in mechanical sensitivity at $24 \mathrm{hr}$. This was reduced by the anti-NGF serum by $40 \%$ in both cases. In sympathectomized animals, the anti-NGF continued to reduce the sensitivity increase by $35 \%$ for thermal and $32 \%$ for mechanical sensitivity (Table 1 ).

\section{Sympathectomy and NGF administration}

To test whether the delay in the induction of a full hyperalgesia in the sympathectomized animals reflected a possible short-lasting sympathetic-dependent action of NGF during the onset of inflammation, the effect of sympathectomy on the hyperalgesia induced by NGF alone was studied. An intraplantar injection of $200 \mathrm{ng}$ of NGF produced a transient $(6 \mathrm{hr})$ mechanical and thermal hyperalgesia in animals with intact sympathetic ncrvous systems (Fig. 3), but the mechanical hypersensitivity to intraplantar NGF was abolished and the thermal hypersensitivity was significantly reduced in sympathectomized animals.

\section{Mast cell degranulation and inflammation}

After depletion of mast cell granules by chronic (4 d) administration of the secretagogue compound $48 / 80$, thermal sensitivity was significantly increased (Fig. 4). The establishment of thermal hyperalgesia after CFA treatment was attenuated at $3 \mathrm{hr}$ and, although the actual values of the thermal sensitivity were identical to that found in control rats at $6-48 \mathrm{hr}$, the changes relative to the preinflammation baseline were diminished (Fig. 4). In contrast, mechanical sensitivity preinflammation was unaffected by admin- 


\section{Thermal Sensitivity}

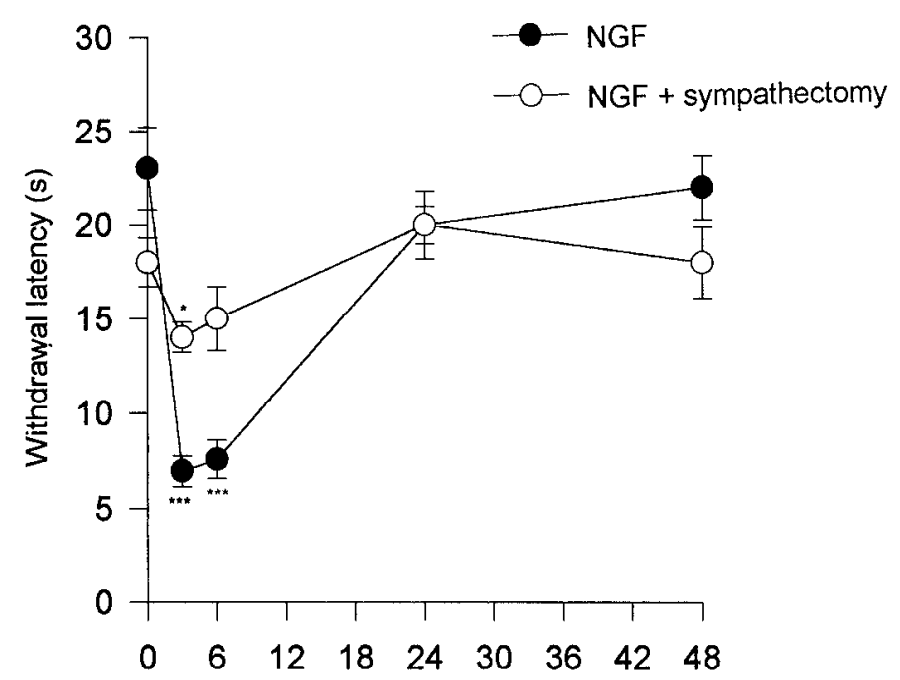

Mechanical Sensitivity

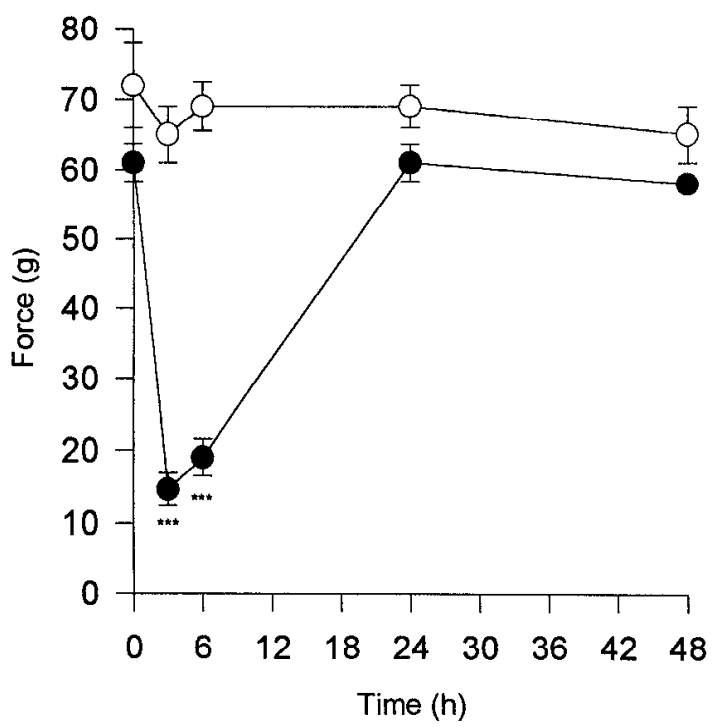

Figure 3. Sympathectomy reduced the transient sensitivity increase produced by intraplantar injection of $200 \mathrm{ng}$ of NGF (*, *** $p<0.05,<0.001$; $n=5$ control, $n=4$ sympathectomy).

istration of compound $48 / 80$, but the hyperalgesia produced by CFA was significantly reduced at all times tested, with the largest change at $3 \mathrm{hr}$, when the animals failed to show any inflammatory hypersensitivity (Fig. 4).

Mast cell depletion did not alter basal IL-1 $\beta$ levels and, although basal NGF levels were increased, this was not quite significant (Fig. 5). The inflammatory upregulation of IL-1 $\beta$ was not affected by mast cell degranulation, but NGF failed to rise significantly above the levels found in noninflamed skin in rats treated with compound 48/80 (Fig. 5).

\section{DISCUSSION}

Inflammatory pain is a multifaceted syndrome that comprises three distinct components: spontaneous pain referred to the site of the inflammation, an amplification of the response to noxious
Thermal Sensitivity

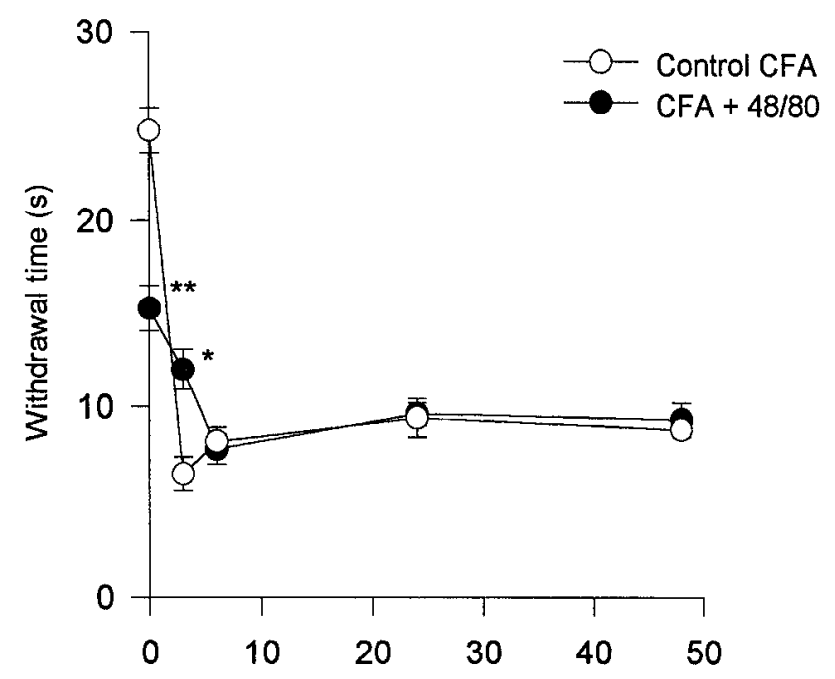

Mechanical Sensitivity

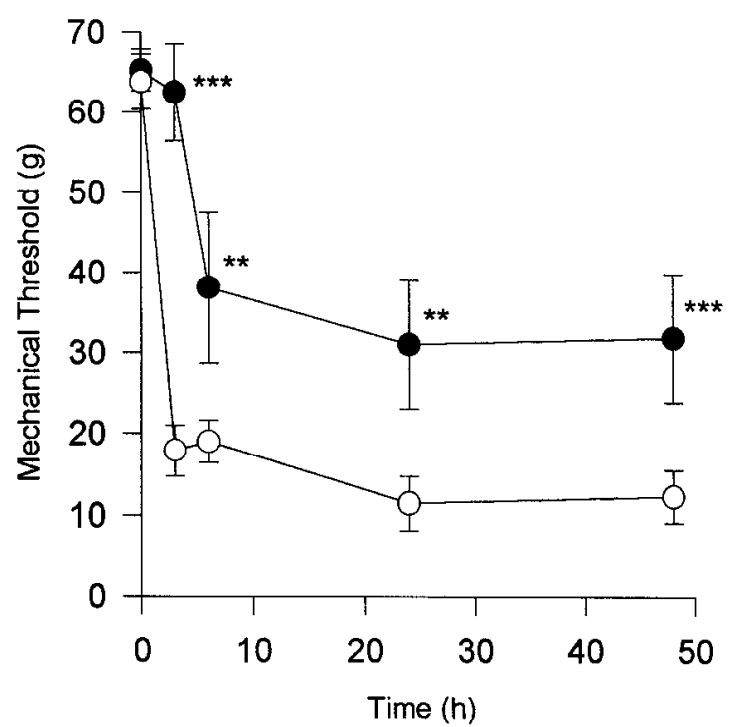

Figure 4. Effect of mast cell degranulation with compound $48 / 80$ on the thermal and mechanical hyperalgesia produced by intraplantar CFA. $n=5$ for CFA group; $n=8$ for $48 / 80$ group $\left[{ }^{*},{ }^{* *},{ }^{* * *}, p<0.05,<0.01\right.$, $<0.001$ CFA (open circles) vs CFA $+48 / 80$ (filled circles) groups].

stimuli-hyperalgesia - and, finally, the generation of pain by what would normally be innocuous stimuli-allodynia. These last two components are manifest both in the inflamed tissue (primary zone) and in the surrounding noninflamed tissue (secondary zone). A number of different mechanisms operating at different times and at different locations contribute to inflammatory pain: direct activation of chemosensitive nociceptors by irritants or inflammatory mediators will elicit spontaneous pain (Handwerker and Reeh, 1991); an alteration in transduction sensitivity of nociceptors by sensitizing mediators like bradykinin or prostaglandin $\mathrm{E}_{2}$ will contribute to primary hyperalgesia (Levine and Taiwo, 1994); whereas sensory input to the spinal cord will sensitize, as a result of the release of excitatory amino acids and neuropeptides, 


\section{IL-1及}

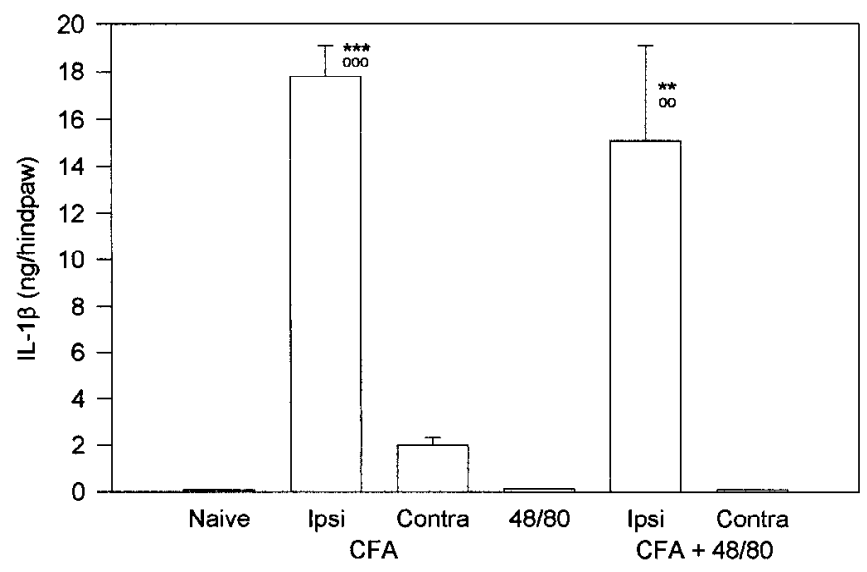

NGF

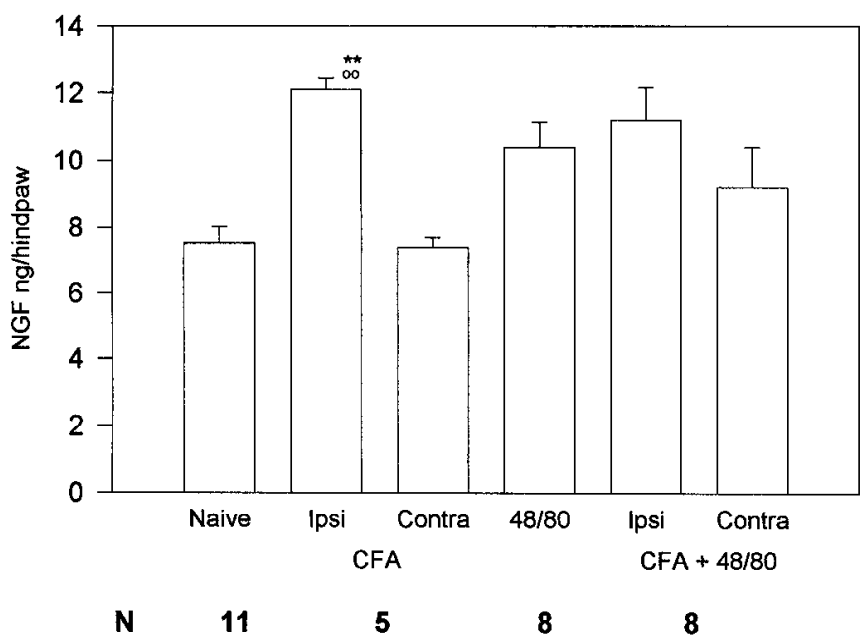

Figure 5. Mast cell degranulation did not alter the inflammatory upregulation of IL- $1 \beta$ but did attenuate that of NGF (oo, ooo, ipsilateral vs contralateral $p<0.01,<0.001 ;{ }^{* *}, * *$, ipsilateral CFA vs naive or ipsilateral CFA $+48 / 80$ vs $48 / 80 p<0.01,<0.001$ ). All measurements were taken $48 \mathrm{hr}$ after CFA injection.

central neurons in an NMDA- and tachykinin receptor-mediated manner to produce secondary hyperalgesia and allodynia (Woolf and Thompson, 1991; Ma and Woolf, 1995). NGF may contribute to inflammatory hypersensitivity by producing both local and central changes in sensitivity.

Neurotrophins have been widely recognized as having a major role in the survival and differentiation of neural crest progenitor cells (Barde, 1989; Crowley et al., 1994; Klein et al., 1994). Their role in the adult was thought, until recently, mainly to mediate those neuron-target interactions responsiblc for maintaining the normal phenotype of the neurons (Lindsay and Harmar, 1989; Lindsay et al., 1989), such that disruption of contact with the neurotrophin in the target by a peripheral axotomy, for example, produced phenotypic changes that could be prevented by neurotrophin replacement (Wong and Oblinger, 1991; Verge et al., 1995). However, we now appreciate that neurological dysfunction in the mature nervous system may occur not only as a result of neurotrophin deficiency, but also as a result of excess.
Inflammation results in an increased production of NGF. This has been shown in inflammatory exudates (Weskamp and Otten, 1987), inflamed soft tissues (Varilek et al., 1991; Aloe et al., 1992; Donnerer et al., 1992; Constantinou et al., 1994; Woolf et al., 1994), and degenerating nerve (Heumann et al., 1987). NGF also results in hyperalgesia when administered systemically in rats, mice, and humans (Lewin et al., 1993; Della Seta et al., 1994; Petty et al., 1994) and locally in rats and humans (Petty et al., 1994; Woolf et al., 1994; Andreev et al., 1995; Safieh-Garabedian et al., 1995). That these two general findings are linked has been shown by the reduction in experimental inflammatory hyperalgesia produced by anti-NGF antibodies (Lewin et al., 1994; Woolf et al., 1994; McMahon et al., 1995). The question that remains is: How and where does NGF contribute to inflammatory hyperalgesia?

NGF produced in peripheral tissue (Bandtlow et al., 1987) will act on those cells in the tissue that express the high-affinity protein tyrosine kinase NGF receptor trkA (Kaplan et al., 1991a; Klein et al., 1991). TrkA is present on inflammatory cells as well as on sympathetic and a subpopulation of small-diameter sensory neurons (Crowley et al., 1994; Averill et al., 1995; Lomen-Hoerth and Shooter, 1995; Wright and Snider, 1995). A cytokine-like action of NGF on inflammatory cells has been noted for some time (Otten, 1991) and includes effects on mast cells, basophils, lymphocytes, and neutrophils leading to proliferation and cytokine production (Aloe and Levi-Montalcini, 1977; Otten et al., 1987; Matsuda et al., 1988a,b; Bischoff and Dahinden, 1992; Kannan et al., 1993; Horigome et al., 1994; Melamed et al., 1995). Although these actions may act to amplify the inflammatory response, they may also contribute indirectly to sensitivity changes by causing the release of inflammatory mediators that then act directly on sensory nerve terminals. Mast cclls, which have a major role in immediate-type hypersensitivity reactions and contribute to chronic inflammation (Marshall and Bienenstock, 1994), are particularly important targets for NGF. NGF promotes their survival (Horigome et al., 1994), growth (Aloe and Levi-Montalcini, 1977), differentiation (Kannan et al., 1993), and degranulation (Mazurek et al., 1986; Pearce and Thompson, 1986; Marshall et al., 1990). Acute degranulation of mast cells releases a number of proteinases, cytokines, and amines, including 5-hydroxytryptamine and histamine (Schwartz, 1994), each of which could sensitize nociceptors, either directly or indirectly via the breakdown of precursor proteins or by inducing the release of inflammatory mediators from other cell types. Chronic degranulation of mast cells with compound 48/80 (Coderre et al., 1989), by depleting the cells of amines and other inflammatory mediators/cytokines, might be interfering with the normal sensitizing consequences of an NGF action on mast cells and, in this way, attenuating inflammatory hyperalgesia. This may not necessarily mean, however, that the role of the mast cell in inflammation relates only to an action of NGF on these cells. Mast cells are also a potential source of NGF production (Leon et al., 1994). We now show that chronic degranulation of mast cells significantly impairs an increase in NGF during inflammation above the levels in noninflamed 48/80treated animals. This may reflect an impairment in the synthesis, storage, or release of NGF from mast cells or a reduction in the release of a cytokine, such as tumor necrosis factor- $\alpha$ from the mast cells, which can act on other cell types to produce NGF (Hattori et al., 1993). The levels of IL-1 $\beta$, which is a powerful inducer of NGF (Lindholm et al., 1987; Safieh-Garabedian et al., 1995), were not affected by $48 / 80$ treatment. The inability to increase NGF levels during inflammation may contribute to the maintained reduction of inflammatory hyperalgesia in these ani- 
mals. This is in contrast to the transient effects of compound $48 / 80$ treatment on the hyperalgesia produced by systemic NGF, which seem to be entirely attributable to a reduction in amine release (Lewin et al., 1994).

Sympathetic neurons are prototypic examples of NGFresponsive neurons (Levi-Montalcini, 1987), and their survival is dependent on access to NGF during development (Crowley et al., 1994). In the present study, removal of postganglionic sympathetic terminals by chemical sympathectomy resulted in an elevation of the basal levels of NGF in the skin, which might reflect either that these cells utilize a considerable component of the normal constitutive production of NGF or that some element of sympathetic innervation of the periphery suppresses NGF production by target tissue. The elevation in basal NGF may have contributed to the increased thermal scnsitivity in the sympathectomized animals, as in a transgenic mouse engineered to overexpress NGF in the skin with a keratin promoter (Davis et al., 1993). The elevation in baseline NGF in the sympathectomized and animals resulted only in a thermal hyperalgesia, whereas in inflammation there is both mechanical and thermal hyperalgesia. This may partly reflect dosage; low doses of intraplantar NGF (2-20 ng) produce thermal but not mechanical hyperalgesia (Woolf et al., 1994), whereas higher doses (200 ng) produce both. Another possibility is that NGF by itself is insufficient to account for all the sensitivity changes produced by inflammation. A dissociation between thermal and mechanical NGF-induced hyperalgesia has been observed previously (Lewin et al., 1994).

The absence of an increase in basal IL- $1 \beta$ levels in the sympathectomized rats shows that the elevated basal NGF levels were not caused by increased levels of this cytokine. NGF upregulation beyond basal levels during inflammation was not affected by sympathectomy, and this treatment only reduced the earliest phase of inflammatory hypersensitivity, with the hyperalgesia present at 6-48 hr after CFA treatment completely unaffected. This initially may seem somewhat surprising in view of the sympathetic dependence of the hyperalgesia produced by intraplantar NGF (Andreev et al., 1995), a finding we now duplicate. The reason for this is likely to be related to timing. Local NGF administration will only elevate NGF concentration in the target for a very brief period and produces a short-lasting hyperalgesia, whereas in CFA-induced inflammation, NGF levels are elevated for at least several days, and the hyperalgesia is persistent. Different mechanisms may operate at different times. NGF may have a trk $A$-mediated action on sympathetic terminals in the periphery that leads to a short-lasting hyperalgesia whenever NGF levels rise acutely. Sympathetic terminals can produce hyperalgesia by releasing eicosanoids or other mediators that sensitize sensory neurons (Levine et al., 1986). A sympathetic-dependent hyperalgesia manifests for several hours after local NGF administration and during the earliest phase of CFA-induced inflammation. Subsequently a nonsympathetic-dependent component contributes to inflammatory hyperalgesia, although this component is NGF-dependent. The time-dependent nature of the involvement of the sympathetic nervous system in inflammatory hyperalgesia may explain the different results in favor of (Levine et al., 1986; Nakamura and Ferreira, 1987) and against (Lam and Ferrell, 1991; Meyer et al., 1992; Perrot et al., 1994; Sluka et al., 1994) a sympathetic dependence of inflammatory hyperalgesia. The question remains, however: What is the mechanism of the NGFdependent contribution to the sympathetic-independent component of inflammatory hyperalgesia?

Both sympathectomy and mast cell degranulation had maximal efficacy in reducing inflammatory hyperalgesia in the first few hours after the onset of inflammation. This is a time when any change must necessarily be restricted to the site of the inflammation, because the retrograde transport of NGF in sensory neurons from the hindpaw to the L4 and L5 DRGs will take 5-7 hr (DiStefano et al., 1992), even before any transcriptional change is effected. Although peripheral sensitization may continue to contribute beyond this time, changes at the DRGs are also likcly to be important. NGF, once it reaches the cell bodies of $\operatorname{trk} A$-expressing sensory neurons in the DRGs will produce, by activating specific signal transduction pathways (Kaplan and Stephens, 1994), alterations in phenotype. This includes the upregulation of neuropeptides, growth-related molecules, and $\mathrm{Na}^{+}$channels (Lindsay and Harmar, 1989; Donnerer et al., 1992; Leslie et al., 1995; ToledoAral et al., 1995). These could contribute to inflammatory hypersensitivity in a number of ways: by promoting peripheral sprouting and the hyperinnervation of inflamed tissue (Leslie et al., 1995); by augmenting neurogenic inflammation after the upregulation of substance P (Lembeck et al., 1992); and, finally, by increasing the central synaptic action of sensory neurons as a result of an increase or novel release of neuropeptide neuromodulators from the central terminals of afferents in the dorsal horn of the spinal cord. Inflammation results in a substantial increase in the numbers of DRG neurons expressing preprotachykinin A and calcitonin gene-related peptide mRNA and in the level of these peptides in the sensory neurons (Noguchi et al., 1988; Donaldson et al., 1992; Safieh-Garabedian et al., 1995), and these changes are NGF-dependent (Donnerer et al., 1992; Woolf et al., 1994; Leslie et al., 1995). An elevation in these neuropeptides may augment the central sensitization normally produced by C-afferent inputs into the spinal cord (Woolf, 1983; Woolf and Wall, 1986) and in this way contribute to inflammatory hypersensitivity.

\section{Conclusions}

NGF is an important mediator in the generation of inflammatory hypersensitivity. In the earliest phase of inflammation, this is attributable exclusively to a peripheral action that is substantially attenuated by either depletion of mast cell granules or sympathectomy. Later phases of inflammatory hypersensitivity are independent of the sympathetic nervous system but are still NGFdependent and likely to reflect both a peripheral action and a transcription-dependent change in the function of sensory neurons.

\section{REFERENCES}

Aberdeen J, Corr L, Milner P, Lincoln J, Burnstock G (1990) Marked increases in calcitonin gene-related peptide-containing nerves in the developing rat following long-term sympathectomy with guanethidine. Neuroscience 35:175-184.

Aloe L, Levi-Montalcini R (1977) Mast cell increase in tissue of neonatal rats injected with nerve growth factor. Brain Res 133:358-366.

Alne I, Tuveri MA, Levi-Montalcini R (1992) Studies on carrageenaninduced arthritis in adult rats: presence of nerve growth factor and role of sympathetic innervation. Rheumatol Int 12:213-216.

Andreev NY, Dimitrieva N, Koltzenburg M, McMahon SB (1995) Peripheral administration of nerve growth factor in the adult rat produces a thermal hyperalgesia that requires the presence of sympathetic postganglionic neurones. Pain 63:109-115.

Averill S, McMahon SB, Clary DO, Reichardt LF, Priestley JV (1995) Immunocytochemical localization of trkA receptors in chemically identitied subgroups of adult rat sensory neurons. Eur $J$ Neurosci 7:1484-1494.

Bandtlow C, Heumann R, Schwab ME, Thoenen H (1987) Cellular localization of nerve growth factor synthesis by in situ hybridization. EMBO J 6:891-899. 
Barde Y-A (1989) Trophic factors and neuronal survival. Neuron 2:1525-1534.

Bischoff SC, Dahinden CA (1992) Effect of nerve growth factor on the release of inflammatory mediators by mature human basophils. Blood 79:2662-2669.

Coderre TJ, Basbaum AI, Levine JD (1989) Neural control of vascular permeability: interactions between primary afferents, mast cells, and sympathetic efferents. J Neurophysiol 62:48-58.

Coderre TJ, Chan AK, Helms C, Basbaum AI, Levine JD (1991) Increasing sympathetic nerve terminal-dependent plasma extravasation correlates with decreased arthritic joint injury in rats. Neuroscience 40:185-189.

Constantinou J, Reynolds ML, Woolf CJ, Safieh-Garabedian B, Fitzgerald M (1994) Nerve growth factor levels in developing rat skin: upregulation following skin wounding. NeuroReport 5:2281-2284.

Crowley C, Spencer S, Nishimura M, Chen KS, Pitts Meek S, Armanini MP, Ling LH, McMahon SB, Shelton DL, Levinson AD (1994) Mice lacking nerve growth factor display perinatal loss of sensory and sympathetic neurons yet develop basal forebrain cholinergic neurons. Cell 76:1001-1011.

Davis BM, Lewin GR, Mendell LM, Jones ME, Albers KM (1993) Altered expression of nerve growth factor in the skin of transgenic mice leads to profound changes in response to mechanical stimuli. Neuroscience 56:789-795.

Della Seta D, de Acetis L, Aloe L, Alleva E (1994) NGF effects on hot plate behaviors in mice. Pharmacol Biochem Behav 49:701-705.

DiStefano PS, Friedman B, Radziejewesk C, Alexander C, Boland P, Schieck CM, Lindsay RM, Wiegand SJ (1992) The neurotrophins BDNF, NT-3 and NGF display distinet patterns of retrograde axonal transport in peripheral and central neurons. Neuron 8:983-993.

Donaldson LF, Harmar AJ, McQueen DS, Seckl JR (1992) Increased expression of preprotachykinin, calcitonin gene-related peptide, but not vasoactive intestinal polypeptide messenger RNA in dorsal root ganglia during the development of adjuvant monoarthritis in the rat. Brain Res Mol Brain Res 16:143-149.

Donnerer J, Schuligoi R, Stein C (1992) Increased content and transport of substance $\mathbf{P}$ and calcitonin gene-related peptide in sensory nerves innervating inflamed tissue: evidence for a regulatory function of nerve growth factor in vivo. Neuroscience 49:693-698.

Green PG, Luo J, Heller PH, Levine JD (1993) Further substantiation of a significant role for the sympathetic nervous system in inflammation. Neuroscience 55:1037-1043.

Handwerker HO, Reeh PW (1991) Pain and inflammation. In: Proceedings of the VIth World Congress on Pain (Bond MR, Charlton JE, Wolf CE, eds), pp 59-70. Amsterdam: Elsevier.

Harvima IT, Horsmanheimo L, Naukkarinen A, Horsmanheimo M (1994) Mast cell proteinases and cytokines in skin inflammation. Arch Dermatol Res 287:61-67.

Hattori A, Tanaka E, Murase K, Ishida N, Chatani Y, Tsujimoto M, Hayashi K, Kohno M (1993) Tumor necrosis factor stimulates the synthesis and secretion of biologically active nerve growth factor in non-neuronal cells. J Biol Chem 268:2577-2582.

Heumann R, Korsching S, Bandtlow C, Thoenen H (1987) Changes of nerve growth factor synthesis in nonncuronal cclls in responsc to sciatic nerve transection. J Cell Biol 104:1623-1631.

Horigome K, Pryor JC, Bullock ED, Johnson EM, Jr (1993) Mediator release from mast cells by nerve growth factor: neurotrophin specificity and receptor mediation. J Biol Chem 268:14881-14887.

Horigome K, Bullock ED, Johnson EMJ (1994) Effects of nerve growth factor on rat peritoneal mast cells. Survival promotion and immediateearly gene induction. J Biol Chem 269:2695-2702.

Kannan Y, Matsuda H, Ushio H, Kawamoto K, Shimada Y (1993) Murine granulocyte-macrophage and mast cell colony formation promoted by nerve growth factor. Int Arch Allergy Immunol 102:362-367.

Kaplan DR, Stephens RM (1991) Neurotrophin signal transduction by the trk receptor. J Neurobiol 25:1404-1417.

Kaplan DR, Hempstead BL, Martin-Zanca D, Chao MV, Parada LF (1991a) The trk prolo-oncogene product: a signal transducing receptor for nerve growth factor. Science 252:554-558.

Kaplan DR, Martin-Zanca D, Parada LF (1991b) Tyrosine phosphorylation and tyrosine kinase activity of the trk proto-oncogene product induced by NGF. Nature $350: 158-160$.

Klein R, Jing S, Nanduri V, O'Rourke E, Barbacid M (1991) The trk proto-oncogene encodes a receptor for nerve growth factor. Cell 65:189-197.
Klein R, Silos-Santiago I, Smeyne RJ, Lira SA, Brambilla R, Bryant S, Zhang L, Snider WD, Barbacid M (1994) Disruption of the neurotrophin-3 receptor gene trkC eliminates Ia muscle afferents and results in abnormal movements. Nature 368:249 251.

Lam FY, Ferrell WR (1991) Neurogenic component of different models of acute inflammation in the rat knee joint. Ann Rheum Dis 50:747-751.

Lembeck F, Donnerer J, Tsuchiya M, Nagahisa A (1992) The nonpeptide tachykinin antagonist, CP-96,345, is a potent inhibitor of neurogenic inflammation. Br J Pharmacol 105:527-530.

Leon A, Buriani A, Dal Toso R, Fabris M, Romanello S, Aloe L, Levi-Montalcini R (1994) Mast cells synthesize, store, and release nerve growth factor. Proc Natl Acad Sci USA 91:3739-3743.

Leslie TA, Emson PC, Dowd PM, Woolf CJ (1995) Nerve growth factor contributes to the upregulation of GAP-43 and preprotachykinin A mRNA in primary sensory neurons following peripheral inflammation. Neuroscience 67:753-761.

Levi-Montalcini R (1987) The nerve growth factor: thirty-five years later. EMBO J 6:1145-1154.

Levine JD, Taiwo YO (1994) Inflammatory pain. In: Textbook of pain (Wall PD, Melzack R, eds), pp 45-56. Edinburgh: Churchill Livingstone.

Levine JD, Moskowitz MA, Basbaum AI (1985) The contribution of neurogenic inflammation in experimental arthritis. $\mathbf{J}$ Immunol 135:843.

Levine JD, Taiwo YO, Collins SD, Tam JK (1986) Noradrenaline hyperalgesia is mediated through interaction with sympathetic postganglionic neurone terminals rather than activation of primary afferent nociceptors. Nature 323:158-160.

Lewin GR, Ritter AM, Mendell LM (1993) Nerve growth factor-induced hyperalgesia in the neonatal and adult rat. J Ncurosci 13:2136-2148.

Lewin GR, Rueff A, Mendell LM (1994) Peripheral and central mechanisms of NGF-induced hyperalgesia. Eur J Neurosci 6:1903-1912.

Lindholm D, Neumann R, Meyer M, Thoenen H (1987) Interleukin-1 regulates synthesis of nerve growth factor in non-neuronal cells of rat sciatic nerve. Nature 330:658-659.

Lindsay RM, Harmar AJ (1989) Nerve growth factor regulates expression of neuropeptide genes in adult sensory neurons. Nature 337:362-364.

Lindsay RM, Lockett C, Sternberg J, Winter J (1989) Neuropeptide expression in cultures of adult sensory neurons: modulation of substance $\mathrm{P}$ and calcitonin gene-related peptide levels by nerve growth factor. Neuroscience 33:53-65.

Lomen-Hoerth C, Shooter EM (1995) Widespread neurotrophin receptor expression in the inmmune system and other nonneuronal rat tissues. J Neurochem 64:1780-1789.

Ma Q-P, Woolf CJ (1995) Involvement of neurokinin receptors in the induction but not the maintenance of mechanical allodynia in the rat flexor motoneurones. J Physiol (Lond) 486:769-777.

Marshall JS, Bienenstock J (1994) The role of mast cells in inflammatory reactions of the airways, skin and intestine. Curr Opin Immunol 6:853-859.

Marshall JS, Stead RH, McSharry C, Nielsen L, Bienenstock J (1990) The role of mast cell degranulation products in mast cell hyperplasia. $\mathbf{I}$. Mechanism of action of nerve growth factor. J Immunol 144:1886-1892.

Matsuda II, Coughlin MD, Bienenstock J, Denburg JA (1988a) Nerve growth factor promotes human hemopoietic colony growth and differentiation. Proc Natl Acad Sci USA 85:6508-6512.

Matsuda H, Switzer J, Coughlin MD, Bienenstock J, Denburg JA (1988b) Human basophilic cell differentiation promoted by $2.5 \mathrm{~S}$ nerve growth factor. Int Arch Allergy Appl Immunol 86:453-457.

Mazurek N, Weskamp G, Erne P, Otten U (1986) Nerve growth factor induces mast cell degranulation without changing intracellular calcium levels. FEBS Lett 198:315-320.

McMahon SB, Armanini MP, Ling LH, Phillips HS (1994) Expression and coexpression of trk receptors in subpopulations of adult primary sensory neurons projecting to identified peripheral targets. Neuron 12:1161-1171.

McMahon SB, Bennett DLH, Priestley JV, Shelton DL (1995) The biological effects of endogenous NGF in adult sensory neurones revealed by a trkA IgG fusion molecule. Nature Med 1:774-780.

Melamed I, Turner CE, Aktories K, Kaplan DR, Gelfand EW (1995) Nerve growth facotr triggers microfilament assembly and paxillin phosphorylation in human B lymphocytes. J Exp Med 181:1071-1079.

Meyer RA, Davis KD, Raja SN, Campbell JN (1992) Sympathectomy does not abolish bradykinin-induced cutaneous hyperalgesia in man. Pain 51:323-327. 
Mousli M, Hugli TE, Landry Y, Bronner C (1994) Peptidergic pathway in human skin and rat peritoneal mast cell activation. Immunopharmacology 27:1-11.

Nakamura M, Ferreira SH (1987) A peripheral sympathetic component in inflammatory hyperalgesia. Eur J Pharmacol 135:145-153.

Noguchi K, Morita Y, Kiyama H, Ono K, Tohyama M (1988) A noxious stimulus induces the preprotachykinin-A gene expression in the rat dorsal root ganglion: a quantitative study using in situ hybridization histochemistry. Brain Res Mol Brain Res 4:31-35.

Otten U (1991) Nerve growth factor: a signalling protein between the nervous and the immune system. In: Towards a new pharmacotherapy of pain (Basbaum AI, Besson J-M, eds), pp 353-363. Chichester: Wiley.

Otten U, Ehrhard P, Peck R (1987) Nerve growth factor induces growth and differentiation of human B lymphocytes. Proc Natl Acad Sci USA 86:10059-10063.

Pearce FL, Thompson HL (1986) Some characteristics of histamine secretion from rat peritoneal mast cells stimulated with nerve growth factor. J Physiol (Lond) 372:379-393.

Perrot S, Attal N, Ardid D, Guilbaud G (1994) Are mechanical and clod allodynia in monineuropathic and arthritic rats relieved by systemic treatment with calcitonin or guanethidine. Pain 52:41-47.

Petty BG, Cornblath DR, Adornato BT, Chaudhry V, Flexner C, Wachsman M, Sinicropi D, Burton LE, Peroutka SJ (1994) The effect of systemically administered recombinant human nerve growth factor in healthy human subjects. Ann Neurol 36:244-246.

Safieh-Garabedian B, Poole S, Allchorne A, Winter J, Woolf CJ (1995) Contribution of interleukin- $1 \beta$ to the inflammation-induced increase in nerve growth factor levels and inflammatory hyperalgesia. Br J Pharmacol 115:1265-1275.

Schwartz LB (1994) Mast cells: function and contents. Curr Opin Immunol 6:91-97.

Sluka KA, Lawand NB, Westlund KN (1994) Joint inflammation is reduced by dorsal rhizotomy and not by sympathectomy or spinal cord transection. Ann Rheum Dis 53:309-314.

Smeyne RJ, Klein R, Schnapp A, Long SK, Bryant S, Lewin A, Lira SA, Barbacid M (1994) Severe sensory and sympathctic ncuropathies in mice carrying a disrupted Trk/NGF receptor gene. Nature 386:246-249.

Stein C, Millan MJ, Herz A (1988) Unilateral inflammation of the hindpaw in rats as a model of prolonged noxious stimulation: alterations in behavior and nociceptive thresholds. Pharmacol Biochem Behav 31:445-451.
Taktak YS, Selkirk S, Bristow AF, Carpenter A, Ball C, Rafferty B, Poole $S$ (1991) Assay of pyrogens by interleukin-6 release from monocyte cell lines. J Pharm Pharmacol 43:578-582.

Toledo-Aral JJ, Brehm P, Halegoua S, Mandel G (1995) A single pulse of nerve growth factor triggers long-term neuronal excitability through sodium channel gene induction. Ncuron 14:607-611.

Treede R-D, Meyer RA, Raja SN, Campbell JN (1992) Peripheral and central mechanisms of cutaneous hyperalgesia. Prog Neurobiol 38:397-421.

Varilek GW, Weinstock JV, Pantazis NJ (1991) Isolated hepatic granulomas from mice infected with Schistosoma mansoni contain nerve growth factor. Infect Immun 59:4443-4449.

Verge VMK, Richardson PM, Wiesenfeld-Hallin Z, Hokfelt T (1995) Differential influence of nerve growth factor on neuropeptide expression in vivo: a novel role in peptide suppression in adult sensory neurons. J Neurosci 15:2081-2096.

Weskamp G, Otten U (1987) An enzyme-linked immunoassay for nerve growth factor (NGF): a tool for studying regulatory mechanisms involved in NGF production in brain and in peripheral tissues. J Neurochem 48:1779-1786.

Wong J, Oblinger MM (1991) NGF rescues substance P expression but not neurofilament or tubulin gene expression in axotomized sensory neurons. J Neurosci 11:543-552.

Woolf CJ (1983) Evidence for a central component of post-injury pain hypersensitivity. Nature 306:686-688.

Woolf CJ, Thompson SWN (1991) The induction and maintenance of central sensitization is dependent on $N$-methyl-D-aspartic acid receptor activation; implications for the treatment of post-injury pain hypersensitivity states. Pain 44:293-299.

Woolf CJ, Wall PD (1986) The relative effectiveness of C primary afferent fibres of different origins in evoking a prolonged facilitation of the flexor reflex in the rat. J Neurosci 6:1433-1443.

Woolf CJ, Reynolds ML, Chong M-S, Emson PC, Irwin N, Benowitz LI (1992) Dencrvation of the motor cndplate results in the rapid expression by terminal Schwann cells of the growth-associated protein GAP43. J Neurosci 12:3999-4010.

Woolf CJ, Safieh-Garabedian B, Ma Q-P, Crilly P, Winter J (1994) Nerve growth factor contributes to the generation of inflammatory sensory hypersensitivity. Neuroscience 62:327-331.

Wright DE, Snider WD (1995) Neurotrophin receptor mRNA expression defines distinct populations of neurons in rat dorsal root ganglia. J Comp Neurol 351:329-338. 